\title{
Seasonality in insect abundance in the "Cerrado" of Goiás State, Brazil
}

\author{
Neuza Aparecida Pereira da Silva ${ }^{1}$, Marina Regina Frizzas² \& Charles Martins de Oliveira ${ }^{3}$
}

1'Centro Universitário de Brasília, SEPN 707/909, Asa Norte, 70790-075 Brasília-DF, Brasil. neuzaaparecida@yahoo.com.br
2Departamento de Zoologia, Instituto de Ciências Biológicas, Universidade de Brasília, 70910-900 Brasília-DF. frizzas@unb.br
${ }^{3}$ Embrapa Cerrados, Caixa Postal 08223, 73310-970 Planaltina-DF, Brasil. Autor para correspondência: charles@cpac.embrapa.br

\begin{abstract}
Seasonality in insect abundance in the "Cerrado" of Goiás State, Brazil. Many studies have provided evidence that tropical insects undergo seasonal changes in abundance and that this is partly due to alternation between the dry and rainy seasons. In the Brazilian "Cerrado" (savannah), this season alternation is particularly evident. The purpose of this work was to study the seasonal abundance of insects in a "Cerrado" area in the municipality of Pirenópolis, Goiás State, Brazil. The insects were captured fortnightly using a light trap between September 2005 and August 2006. The insects collected were separated at the order level and counted. Faunistic analysis was performed to select the predominant insect orders, a multiple linear regression to examine the relation between climatic variables (temperature and precipitation) with the abundance of insects and a circular distribution analysis to evaluate the existence of seasonality in the abundance of insect orders. A total of 34,741 insect specimens were captured, belonging to 19 orders. The orders with the greatest number of specimens were Hymenoptera $(8,022)$, Coleoptera $(6,680)$, Diptera (6,394), Lepidoptera $(6,223)$, Isoptera $(2,272)$, Hemiptera $(2,240)$ and Trichoptera $(1,967)$, which represent $97.3 \%$ of all the specimens collected. All the orders, except for Diptera, Isoptera and Trichoptera, showed a relationship with the climate variables (temperature), and all the orders, except for Diptera, presented a grouped distribution, with greater abundance in the transition from the end of the dry season (September) to the start of the rainy one (October/November). A discussion about seasonality on the abundance of the insects is presented.
\end{abstract}

KEYWORDS. "Cerrado" biome; Insecta; light trap; seasonal variation.

RESUMO. Sazonalidade na abundância de insetos no Cerrado de Goiás, Brasil. Alguns estudos fornecem evidências de que os insetos tropicais possuem variação na abundância entre as estações seca e chuvosa. No Cerrado brasileiro, a alternância entre seca e chuva é particularmente evidente. O objetivo desse estudo foi avaliar se existe variação sazonal na abundância de insetos em uma área de Cerrado em Pirenópolis, Goiás, Brasil. As amostras foram coletadas quinzenalmente com armadilha luminosa, entre setembro/2005 e agosto/2006. Os insetos coletados foram separados em nível de ordem e contados. Foi realizada uma análise faunística para selecionar as ordens de insetos predominantes, uma regressão linear múltipla para verificar a relação das variáveis climáticas (temperatura e precipitação) com a abundância de insetos e uma análise circular de distribuição para se avaliar a existência de sazonalidade na abundância das ordens de insetos. Foram coletados 34.741 espécimes de insetos pertencentes a 19 ordens. As ordens com mais espécimes foram Hymenoptera (8.022), Coleoptera (6.680), Diptera (6.394), Lepidoptera (6.223), Isoptera (2.272), Hemiptera (2.240) e Trichoptera (1.967), que somaram 97,3\% do total coletado. Todas as ordens, com exceção de Diptera, Isoptera e Trichoptera, apresentaram relação com temperatura, e todas as ordens com exceção de Diptera, apresentaram distribuição agrupada, com maior abundância na transição seca (setembro) e chuva (outubro/novembro). Discussão sobre a sazonalidade na abundância dos Insecta é apresentada.

PALAVRAS-CHAVE. Armadilha luminosa; bioma Cerrado; Insecta; variação sazonal.

The distribution, abundance and richness of insect species can be influenced by the climate, vegetation and their interactions (Wolda 1978; Marinoni \& Ganho 2003; Kittelson 2004; Torres \& Madi-Ravazzi 2006). Food resources and climate conditions vary in space and time, directly affecting the diversity and distribution of insect populations (Morais et al. 1999; Kittelson 2004; Bispo et al. 2006; Bispo \& Oliveira 2007; Goldsmith 2007). Climate is one of the determining factors in insect population fluctuations during the year (Wolda 1978; Torres \& Madi-Ravazzi 2006).

Seasonal pattern can be defined as a phenomenon such as the abundance of active adults, appearance of reproductive activity or of dispersal may occur only at certain times of the year or it may occur year-round. In the latter case it is still considered seasonal if there are well-defined seasonal maxima (Wolda 1988). Variation in insect abundance in tropical regions is a well established fact (Wolda 1978; Wolda 1980;
Wolda \& Fisk 1981; Pinheiro et al. 2002), but little is known about the factors that determine this seasonality. In the tropics there is variation of climate conditions that can affect the seasonal patterns of insects (Wolda \& Fisk 1981). One of the most important factors in many regions is the change from the dry to the rainy season (Wolda 1988). However, it cannot be expected that ecologically and taxonomically different groups respond in the same manner to shifts in climate variables (Wolda \& Fisk 1981).

The "Cerrado" biome occupies an area of approximately 204.7 million hectares in Brazil, corresponding to $24 \%$ of the country's territory (IBGE 2004). It covers practically the entire Midwest region, parts of the North, Northeast and Southeast regions and only $2 \%$ of the South region (Ribeiro \& Walter 1998; Sano et al. 2008). It contains about $30 \%$ of Brazil's biodiversity (Dias 1996) and is one of the most threatened biomes in the world (Mittermeier et al. 2005). The 
"Cerrado" biome presents two well-defined seasons, being a rainy season (October to March) and a dry season (April to September), and average annual precipitation of about 1,400 $\mathrm{mm}$ in the central portion of the biome (Castro et al. 1994; Silva et al. 2008). The availability of water determines the plant growth cycles, increasing or decreasing the availability of food resources for herbivores. However, there is little or no information on the distribution and abundance patterns of most "Cerrado" insect taxa, and how climate factors can affect their population dynamics (Pinheiro et al. 2002). Studies on population dynamics of a species or group of organisms generally include details regarding the number of individuals, mortality factors, reproduction, recruitment and dispersal over the years (Wolda 1988, 1992). For studies involving the abundance and species diversity, basis for adoption of conservation measures, especially in highly threatened biomes as the "Cerrado", the knowledge of seasonality, in different taxonomic levels, is very important.

The purpose of this work was to study the seasonality in abundance of insects in a "Cerrado" area in the municipality of Pirenópolis, Goiás State, Brazil.

\section{MATERIAL AND METHODS}

Study Area. The study was carried out in a "Cerrado" area of approximately 30 hectares located within the Pirineus State Park Environmental Protection Area (APA dos Pirineus) in the municipality of Pirenópolis, Goiás (48 56' 53' W; $\left.15^{\circ} 50^{\prime} 15^{\prime} \mathrm{S} ; 783 \mathrm{~m}\right)$. The local phytophysionomy is classified as "Cerradão", characterized by the predominance of arboreal species (on average taller than $15 \mathrm{~m}$ ), with the formation of a continuous canopy cover, without association with watercourses (Ribeiro \& Walter 2008).

Insect collection. During one year, between September 2005 and August 2006, twice-monthly insect collections were carried out using a light trap similar to the INTRAL model, with an F15T8 BLB fluorescent bulb coupled to a recipient containing $70 \%$ alcohol and detergent. The trap was fixed approximately $2 \mathrm{~m}$ above the ground and connected to an electrical outlet. Light trap remained turned on for $12 \mathrm{~h}$ (6:00 p.m. to 6:00 a.m.) and was always installed at the same point. The insects captured were transferred to vials containing $70 \%$ alcohol and transported to the laboratory, where they were sorted at the order level and counted. All the insects captured were deposited into the Centro Universitário de Brasília (UniCEUB) collection. The climatic data (temperature and precipitation) of the Pirenópolis area were obtained from the Goiás Station of the National Institute of Meteorology (Station 83376 - $10^{\circ}$ DISME/INMET - Pirenópolis/GO).

Statistical analysis. Faunistic analysis is a tool used to characterize and define communities, to measuring environmental impact, to determine predominant taxa and to compare areas based on insect species (Frizzas et al. 2003). In this work faunistic analysis was used to determine the predominant orders, according to the dominance, abundance, frequency and constancy indexes (Silveira Neto et al. 1995). The dominance index is defined based on the frequency of occurrence of each taxon in relation to a limit of dominance defined as the inverse of the number of taxa collected multiplied by 100 . Abundance index is a dispersion measure based in the determination of standard deviation, mean standard error and confidence interval ( $1 \%$ and $5 \%$ probability) using the $t$ distribution. Frequency index is defined as the percentage of individuals of a given taxa in relation to the total population. Constancy index is the relationship between the number of samples on which a given taxa occurred and the total number of samples. The indexes were calculated by using the ANAFAU program (RCB Moraes et al., unpublished data).

To verify the relationship between abundance of the predominant insect orders and the climate variables (total monthly precipitation and average monthly temperature), a multiple linear regression was performed according to Pinheiro et al. (2002), by using the SAS statistical program (SAS Institute 2001). In this analysis the dependent variable was the number of insects collected per month (per insects order) and the predictors variables were the total monthly precipitation and average monthly temperature. The DurbinWatson test (Durbin \& Watson 1950) was used to verify the independence of the sampling dates. This test verifies the existence or not of autocorrelation for the residual values.

Since the insect abundance over time does not show a linear increment, but constitutes a periodic process (Pinheiro et al. 2002), it was verified the existence of seasonality in the abundance of the insect orders by a circular analysis (Zar 1999), which permits determining the occurrence of population peaks. Measure of concentration $(r)$ was calculated, whose value varies from 0 (maximum dispersion of the data) to 1 (maximum concentration of the data in the same direction), and the circular standard deviation (So) was calculated as well (Zar 1999) by using the Oriana 2.02 program (Kovach 2004).

\section{RESULTS}

A total of 34,741 insect specimens belonging to 19 orders were collected. The orders with the greatest number of specimens were Hymenoptera $(8,022)$, Coleoptera $(6,680)$, Diptera $(6,394)$, Lepidoptera $(6,223)$, Isoptera $(2,272)$, Hemiptera $(2,240)$ and Trichoptera $(1,967)$. Together these orders represented $97.3 \%$ of all the specimens collected (Table I). Hymenoptera, Coleoptera, Diptera and Lepidoptera were the orders with the largest faunistic indexes and were classified as dominant, very abundant, very frequent and constant (Table I). Hemiptera and Trichoptera were dominant, common, frequent and constant; and Isoptera was dominant, common, frequent and accessory (Table I). The other orders (Psocoptera, Ephemeroptera, Blattodea, Thysanoptera, Dermaptera, Strepsiptera, Orthoptera, Plecoptera, Neuroptera, Mantodea, Megaloptera and Embioptera) represented only $2.7 \%$ of the total number of collected specimens (Table I) and were not considered in this study.

Regarding abundance (sum of all the specimens collected), the Insecta class displayed the highest abundance 
Table I. Total number of specimens per order, number of collections, faunistic indexes (dominance, abundance, frequency and constancy) for the Insecta captured in light trap in a "Cerrado" area in Pirenópolis, Goiás State, Brazil, from September 2005 to August 2006.

\begin{tabular}{|c|c|c|c|c|c|c|}
\hline Orders & $\mathrm{N}^{\circ}$ specimens & $\mathrm{N}^{\circ}$ collections & Dominance ${ }^{1}$ & Abundance ${ }^{2}$ & Frequency ${ }^{3}$ & Constancy ${ }^{4}$ \\
\hline Blattodea & 126 & 16 & ND & $\mathrm{r}$ & $\mathrm{LF}$ & W \\
\hline Coleoptera & 6,680 & 23 & $\mathrm{D}$ & va & VF & $\mathrm{W}$ \\
\hline Dermaptera & 80 & 3 & ND & $\mathrm{r}$ & LF & Z \\
\hline Diptera & 6,394 & 24 & $\mathrm{D}$ & va & VF & W \\
\hline Embioptera & 1 & 1 & ND & r & $\mathrm{LF}$ & Z \\
\hline Ephemeroptera & 257 & 12 & ND & $\mathrm{d}$ & $\mathrm{LF}$ & $\mathrm{Y}$ \\
\hline Hemiptera & 2,240 & 24 & $\mathrm{D}$ & $\mathrm{c}$ & $\mathrm{F}$ & $\mathrm{W}$ \\
\hline Hymenoptera & 8,022 & 24 & $\mathrm{D}$ & va & VF & $\mathrm{W}$ \\
\hline Isoptera & 2,272 & 10 & $\mathrm{D}$ & $\mathrm{c}$ & $\mathrm{F}$ & $\mathrm{Y}$ \\
\hline Lepidoptera & 6,223 & 23 & $\mathrm{D}$ & va & VF & W \\
\hline Mantodea & 11 & 6 & ND & r & LF & Z \\
\hline Megaloptera & 3 & 2 & ND & r & $\mathrm{LF}$ & $\mathrm{Z}$ \\
\hline Neuroptera & 15 & 8 & ND & $\mathrm{r}$ & LF & Z \\
\hline Orthoptera & 17 & 10 & ND & r & $\mathrm{LF}$ & Y \\
\hline Plecoptera & 17 & 3 & ND & $\mathrm{r}$ & LF & $\mathrm{Z}$ \\
\hline Psocoptera & 276 & 23 & ND & d & $\mathrm{LF}$ & W \\
\hline Strepsiptera & 43 & 8 & ND & r & $\mathrm{LF}$ & $\mathrm{Y}$ \\
\hline Thysanoptera & 97 & 10 & ND & $\mathrm{r}$ & LF & $\mathrm{Y}$ \\
\hline Trichoptera & 1,967 & 22 & $\mathrm{D}$ & $\mathrm{c}$ & $\mathrm{F}$ & W \\
\hline
\end{tabular}

${ }^{1}$ Dominance: dominant (D), non-dominant (ND); ${ }^{2}$ Abundance: rare (r), dispersed (d), common (c), very abundant (va); ${ }^{3}$ Frequency: low frequency (LF), frequent $(\mathrm{F})$, very frequent $(\mathrm{VF}) ;{ }^{4}$ Constancy: constant $(\mathrm{W})$, accessory $(\mathrm{Y})$, accidental $(\mathrm{Z})$.

between September and November and smaller abundance between December and August. Hymenoptera presented population peaks in September and November, highest abundance between September and January, and very low number of specimens from April on. Coleoptera showed greater number of specimens captured between September and November and smaller abundance between December and August. Diptera diplayed an erratic distribution throughout the year with population peaks in October, March and June. Lepidoptera and Hemiptera presented a similar abundance pattern, with population peaks in September and October, and a relatively high abundance between November and August. Specimens of Isoptera were restricted to the period from September to January, with population peaks in September and November. For Trichoptera, the population peak was in October and the period during which the highest number of specimens collected was recorded was between September and December, with very small number of specimens collected from January to August (Figure 1).

The abundance of the Insecta class and of the Hymenoptera, Coleoptera, Lepidoptera and Hemiptera orders were significantly related to the climate variables, with this correlation only in function of temperature (Insecta: $\mathrm{R}^{2}=$ $0.70, \mathrm{P}=0,0041$; Hymenoptera: $\mathrm{R}^{2}=0.51, P=0.0413$; Coleoptera: $\mathrm{R}^{2}=0.64, P=0.0101$; Lepidoptera: $\mathrm{R}^{2}=0.77$, $P=0.0012$ and Hemiptera: $\mathrm{R}^{2}=0.84, P=0.0003$ ) (Table II).
Table II. Multiple linear regression for climate variables (average monthly temperature and total monthly precipitation) and the total of insects and main Insecta orders captured in light trap in a "Cerrado" area in Pirenópolis, Goiás State, Brazil, from September 2005 to August 2006.

\begin{tabular}{lccrc}
\hline \multicolumn{1}{c}{ Taxa } & $\mathrm{R}^{2}$ & $\mathrm{DF}$ & $\mathrm{F}$ & $P$ \\
\hline Insecta $^{1}$ & 0.70 & 9 & 10.72 & $0.0041^{* *}$ \\
Hymenoptera & 0.51 & 9 & 4.64 & $0.0413^{*}$ \\
Coleoptera & 0.64 & 9 & 7.98 & $0.0101^{*}$ \\
Diptera & 0.41 & 9 & 3.08 & $0.0954^{\mathrm{ns}}$ \\
Lepidoptera & 0.77 & 9 & 15.38 & $0.0012^{* *}$ \\
Isoptera & 0.45 & 9 & 0.86 & $0.4539^{\mathrm{ns}}$ \\
Hemiptera & 0.84 & 9 & 23.06 & $0.0003^{* *}$ \\
Trichoptera & 0.45 & 9 & 3.72 & $0.0663^{\mathrm{ns}}$ \\
\hline
\end{tabular}

${ }^{1}$ Sum of all the specimens collected; * significant $(P<0,05)$;* significant $(P<0,01)$ and ns not significant; Degrees of freedom for error.

The circular analysis showed that in general the Insecta class had a clustered distribution $(r=0.572)$ in the transition from the end of the dry season (September) to the start of the rainy one (October and November) (Table III; Figure 1), the period when $68.4 \%$ of the specimens were collected. The same pattern was observed for the orders Hymenoptera $(r=$ $0.636)$, Coleoptera $(r=0.649)$, Lepidoptera $(r=0.519)$, Isoptera $(r=0.900)$, Hemiptera $(r=0.445)$ and Trichoptera $(r=0.822)$, which presented, respectively, 67,3; 74,3; 64,0; 

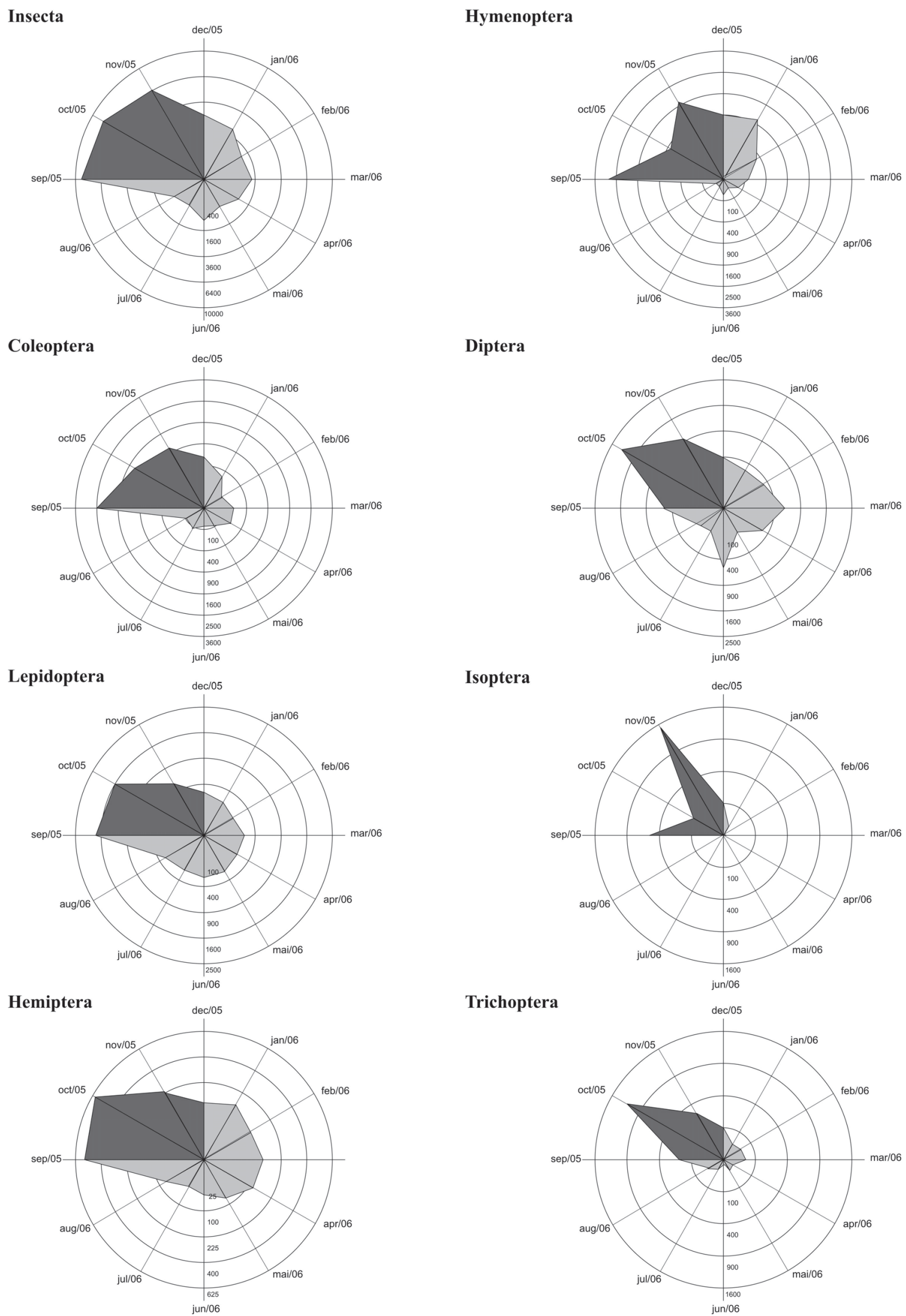

Trichoptera

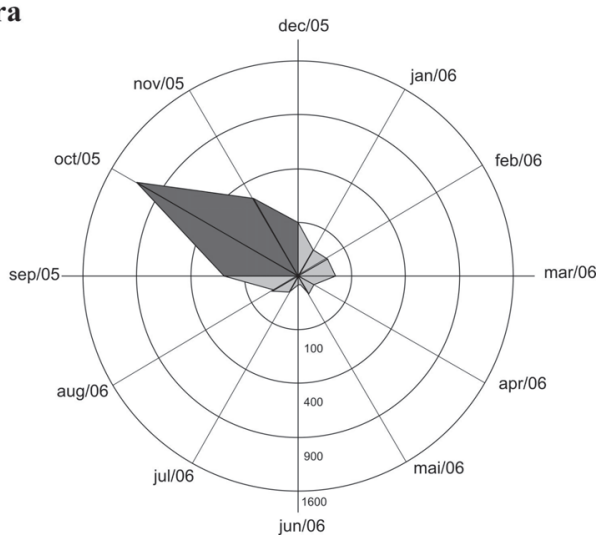

Fig. 1. Circular graph of abundance of total insects and the main Insecta orders captured in a light trap in a "Cerrado" area in Pirenópolis, Goiás State, Brazil, from September 2005 to August 2006. The darker area in each graph refers to the transition period from the end of the dry season (September) to the start of the rainy season (October and November). 
94,$9 ; 61,1$ and $85,2 \%$ of the specimens collected in the same period. Lepidoptera adults, although having a clustered distribution, were observed in large numbers in the dry season (Figure 1), representing $49.6 \%$ of the specimens captured. The Diptera order displayed a random distribution $(r=0.386)$ throughout the year (Table III; Figure 1).

Table III. Measure of concentration ( $r$ ), circular standard deviation (So), distribution and season of the year with highest abundance for total insects and the main Insecta orders captured in light trap in a "Cerrado" area in Pirenópolis, Goiás State, Brazil, from September 2005 to August 2006.

\begin{tabular}{lcccc}
\hline \multicolumn{1}{c}{ Taxa } & $r$ & So & Distribution & Season \\
\hline Insecta $^{1}$ & 0.572 & 60.541 & Clustered & Dry/Rainy ${ }^{2}$ \\
Hymenoptera & 0.636 & 54.482 & Clustered & Dry/Rainy \\
Coleoptera & 0.649 & 53.239 & Clustered & Dry/Rainy \\
Diptera & 0.386 & 79.043 & Random & - \\
Lepidoptera & 0.519 & 65.629 & Clustered & Dry/Rainy \\
Isoptera & 0.900 & 26.307 & Clustered & Dry/Rainy \\
Hemiptera & 0.445 & 72.900 & Clustered & Dry/Rainy \\
Trichoptera & 0.822 & 35.870 & Clustered & Dry/Rainy \\
\hline
\end{tabular}

Sum of all the specimens collected. ${ }^{2}$ Transition from the end of the dry season (September) to the start of the rainy one (October and November).

\section{DISCUSSION}

We observed in this study that "Cerrado" insects have seasonal pattern in its abundance during the year. All the taxa studied, except for the Diptera order, showed a clustered distribution, with highest abundance in the transition period from the end of the dry season to the start of the rainy one (Table III; Figure 1). The greatest number of specimens was collected in the rainy season (62.8\%). The seasonality of tropical insects has been studied in Brazil since the mid twentieth century (Davis 1945; Dobzhansky \& Pavan 1950). In the tropics, the period of insect activity is on average longer, the percentage of species active throughout the year is greater and the peaks of abundance are less well defined than in temperate areas. However, there is a seasonal gradient in the tropics, which is more accentuated in areas with well-defined dry seasons. However, there are also areas where there is practically no seasonality (Wolda 1978, 1980, 1988).

The most pronounced climate characteristic of the Brazilian "Cerrado" is its bimodal rainfall distribution, with a well-defined dry season from April to September and a rainy one from October to March (Silva et al. 2008). In areas with well-defined rainfall cycles, insects tend to be less abundant in the dry season (Wolda 1978). In this study we observed that besides higher precipitation, there was also an increase in temperature in September and October, which coincides with the start of the rainy season (Figure 2). Temperature is one of the climate variables that most influences the activity of many insect species, determining their rates of development and reproduction. The seasonality of insects has been

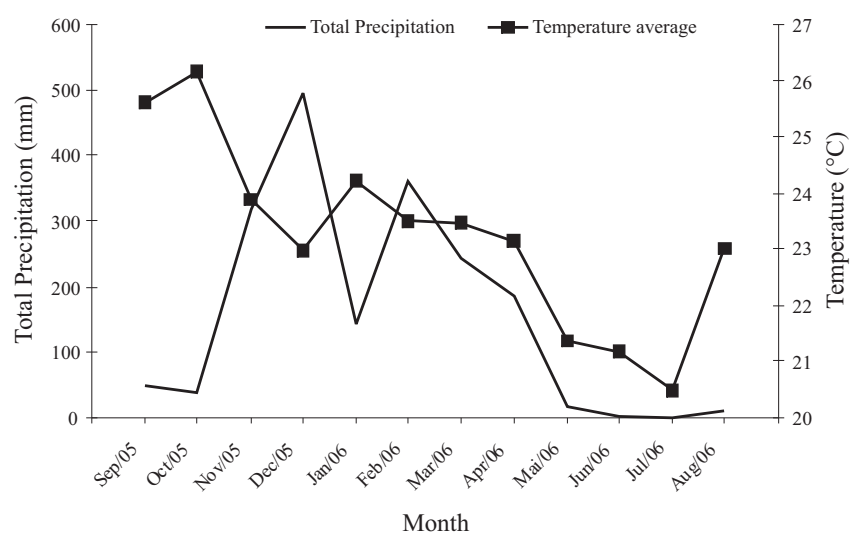

Fig. 2. Total monthly precipitation and average monthly temperature from September 2005 to August 2006 in Pirenópolis, Goiás State, Brazil.

modeled successfully based on this variable (Brakefield 1987; Wolda 1988). Relative air humidity and precipitation also have a strong influence on the seasonal pattern of tropical insects, but often no direct correlations are found with the seasonality of these organisms during the year. However, there is evidence that in the tropics the first rains at the end of the dry season act as a trigger for resumption of insect activity (Wolda 1988). Therefore, the increase in temperature, which showed a significant positive relation with abundance $\left(\mathrm{R}^{2}=\right.$ 0.70 and $P=0.0041)$, and the increased availability of water, provided by the first rains in September $(50 \mathrm{~mm})$, appear to be the factors favoring the increase in insect populations in the "Cerrado". The influence of soil water availability in the abundance of edaphic insects in the "Cerrado" has already been observed (Oliveira et al. 2006).

The changes in climate variables (increased temperature and precipitation) that occur gradually in the transition from the end of the dry season (September) to the start of the rainy one (October) coincide with the peak production of leaves and flowers in the "Cerrado" (Morais \& Diniz 2004; Oliveira 2008). Newer leaves contain lower toxin levels, are softer and have higher nutrient content (Feeny 1970). This availability of resources plays an important role in the seasonable patterns of insects (Wolda 1978, 1988). Therefore, the insect populations in the "Cerrado", mainly of herbivores, appear to be synchronized with the increased availability of food resources in this period.

In another study carried out in the "Cerrado" of Central Brazil, using malaise tent, pitfall and window traps, Hymenoptera, Coleoptera, Diptera, Lepidoptera, Isoptera and Hemiptera, were also the most abundant orders (Pinheiro et al. 2002), but with differences regarding peaks of abundance for each of the orders. The exception was Trichoptera, that also was abundant in our study.

The swarming behavior of the Hymenoptera for dispersal with the first rains, which occur in September in the "Cerrado", is well known and occurs in synchronized form among individuals of the various colonies of the same species and even of other species (Della Lucia \& Bento 1993). 
Furthermore, the habits of many species of Hymenoptera, such as pollinators, parasitoids and predators, may also have contributed for the clustered distribution of this order, since the greater availability of food resources such as flowers (Morais \& Diniz 2004), hosts and prey occur at the end of the dry season and during the rainy season.

In the Brazilian "Cerrado" some Coleoptera species, such as Phyllophaga capillata (Blanchard, 1850) (Melolonthidae) and Aegopsis bolboceridus (Thomson, 1860) (Melolonthidae), spend the dry season underground, in larval diapause, and then change into adults in the second half or end of the dry season. The adults only abandon the soil to mate and disperse when the temperature rises and the first rains begin (September/October) and can be captured in light traps until December (Oliveira et al. 2007b, 2008). This can be one of the explanations for the abundant collection of Coleoptera starting with the first rains and rise in temperature in September 2005 (Figure 2). The higher abundance of the Coleoptera in this period can also be related to the greater food availability (Huston 1996). Increased temperature and soil moisture from increased precipitation favor the development of plants, which serve as food for many species of Coleoptera. In a study conducted in an area of eucalyptus trees in the "Cerrado" in Minas Gerais State, higher Coleoptera abundance was also observed in September and October, corresponding to the end of the dry season and start of the rainy one (Pinto et al. 2000). In Central Brazil, in an area of native "Cerrado" vegetation, this order presented a clustered distribution in the first half of the rainy season (October to December) (Pinheiro et al. 2002). This same pattern was observed in the Atlantic Rainforest in São Paulo State (Gnaspini et al. 2000) and in the "caatinga" biome (scrublands) for the Buprestidae family (Iannuzzi et al. 2006). In cooler regions of the country, such as the southern Paraná State, the seasonal abundance of Nyssodrysina lignaria (Bates, 1864) (Cerambycidae) appears to coincide with warmer periods (Marinoni \& Ganho 2003). In humid tropical regions, the seasonality of Coleoptera has also been observed, with higher abundance in the wetter period (Noriega et al. 2007), but this difference is not as notable as in regions where there is a well-defined dry season, as in the "Cerrado".

Despite the random distribution of Diptera populations during the year, there were peaks in the number of collected specimens in October, March and June (Figure 1). Some other studies in Brazil have shown that even within a single family or genus, there are large seasonal variations of Diptera abundance, with some species being more abundant in drier periods and others in wetter ones (Torres \& Madi-Ravazzi 2006; Oliveira et al. 2007a). The Diptera form a group with very heterogeneous habitats and feeding habits. In roughly half the species of this order the immature forms can develop in practically any aquatic environment and the other half in land environments, feeding on a wide range of substrates (Teskey 1991; Guimarães \& Amorin 2006). This flexibility in the exploitation of environments and food sources for development of immature forms perhaps explains why some species of this order are found throughout the year while others concentrate in the rainy or dry season.

Lepidoptera adults, although having a clustered distribution, were observed in large numbers in the dry season (Figure 1). Certain Lepidoptera can survive the dry season in the adult phase (DeVries 1987) and some studies have also shown that in the "Cerrado" the immature forms of Lepidoptera show abundance peaks in May and July, in the middle of the dry season (Morais et al. 1999). This same pattern has been observed in "restinga" vegetation (Monteiro et al. 2007). Active caterpillars are found during the dry season feeding from mature leaves that have lower pubescence than the new leaves found at the start of the rainy period, which are less suitable food sources for immature Lepidoptera (Morais et al. 1999). This is possible because in the "Cerrado", unlike in deciduous forests, plants in the majority of phytophysiognomies do not shed their mature leaves during the dry season. Hence, many of these species that occur in the active immature form in the dry season can develop into adults during this same period. This can explain the high percentage of specimens of this order collected during the dry months.

The majority of Lepidopdera species are phytophagous (Dias 2006) and can use various strategies to survive during the dry season. Some species survive in larval diapause and some as pupae, with both types becoming adults in the rainy season (Janzen 1987; Aiello 1992). In this study, was observed that the Lepidoptera species showed a highly significant relation with the increase in temperature starting in September (Figure 2). Perhaps this temperature rise and the start of the rains in September $(50 \mathrm{~mm})$ can be decisive factors for the emergence of adults at this time, either from larval diapause or pupal phase (Janzen 1987; Aiello 1992). However, in other Brazilian biomes, such as the Atlantic Rainforest in the Pernambuco State, no seasonality has been observed among the Sphingidae fauna (Duarte Júnior \& Schlindwein 2005), perhaps because in that forest the relatively steady climate conditions and plentiful leaves and flowers the year round permit the development of Lepidoptera populations in all seasons.

The seasonal pattern of insect abundance is synchronized with the availability of food resources, which can vary seasonally with the climate (Wolda 1978). Therefore, insects that feed on plant sap, as the majority of Hemiptera species do, can exploit this food resource throughout the year. However, new leaves generally have lower toxin levels, are softer, have higher nutrient content (Feeny 1970) and are more suitable for sap feeders (Wolda 1978; Ott et al. 2006). The fact that in the "Cerrado" most plant species grow new leaves at the end of the dry season and start of the rainy one (Morais \& Diniz 2004; Oliveira 2008) may explain the higher abundance of this order in this period. Besides this, among the taxa studied, Hemiptera showed the strongest relationship with the climate variables (temperature), indicating that the increase in temperature in this period is likely a decisive factor for population growth of these insects.

About 290 species of Isoptera have been identified in Brazil (Constantino 1999, 2002) and the representants of this 
order are particularly abundant in "Cerrado" regions. In Brazil, the Isoptera species have been observed in swarming at the start of the rainy season, mainly at night (Mill 1983; Medeiros et al. 1999). Therefore, the abundant collection of representatives of the Isoptera order was exclusively due to the capture of winged adults during flights to mate and disperse, since a light trap only attracts and captures winged specimens with nocturnal habits. Among the taxa studied, the Isoptera had the highest measure of concentration, meaning that all the specimens were collected in a single season of the year (September to January). In Atlantic Rainforest areas, where there is not such a pronounced dry period as in "Cerrado" areas, the swarming period can extend for nine months (November to July) (Medeiros et al. 1999). Although not observed a relation between the abundance of Isoptera species and the climate variables, precipitation is the main mechanism for these insects to start swarming (Mill 1983).

Like for the Isoptera, the Trichoptera presented a highly clustered distribution, with $61.4 \%$ of all adults being collected at the start of the rainy season (October). Immature Trichoptera are aquatic and inhabit lotic and lentic environments. The majority of studies on the seasonal patterns of Trichoptera in the "Cerrado" have been restricted to the immature phases (Shuvartz et al. 2005; Bispo et al. 2006; Bispo \& Oliveira 2007). For larvae, in the "Cerrado" of Goiás, higher abundance was observed in the dry season (Shuvartz et al. 2005). Many Trichoptera adults are captured in light traps when leaving the watercourses, that are the sites of egglaying and the initial phase of their development (Marinoni \& Almeida 2000; Almeida \& Marinoni 2000). In this study, there was a small watercourse about 60 meters from the light trap, which may explain the substantial number of Trichoptera captured. The large number of Trichoptera adults captured at the start of the rainy season suggests that the greater availability of water in hydrographic basins in this season synchronizes the emergence of adults, which thus have more places to lay eggs and subsequent development of larvae.

Light traps provide reliable information on changes in the real size of populations of many species of night-flying insects (Wolda 1978), but do not reflect the relative abundance of all species in a determined area. Therefore, this type of trap should not be used to estimate the size or density of insect populations in general, but can be a good tool to estimate changes in abundance (Wolda 1992). Each type of trap samples a portion of the insect population and the results are not necessarily comparable among different types of trap. In a similar study to that presented here, in a "Cerrado" region but using other types of traps (malaise, pitfall and window), lower measures of concentration were found; the Diptera, Homoptera, Lepidoptera and Orthoptera orders were considered random (dispersed); only Coleoptera presented a relationship with the climate variables; and the abundance peak of the orders with clustered distribution occurred in the rainy season (Pinheiro et al. 2002). This shows that the combined use of several trap types can help in better understanding the seasonality of tropical insects.
The seasonal abundance of insects cannot be explained only by one or a group of climate factors, although climate certainly has a great influence on it. Many other factors, such as interspecific competition, predation, parasitism, distribution of a food resource at a particular time of the year, among others, appear to act together with climate factors to mold the patterns of distribution and abundance of insects. The data presented and discussed in this study are based on the order level. It is known, however, that huge variations in seasonality can occur among insect species within each order. This can sometimes cause bias in interpreting the data. However, we observed that in the "Cerrado" the seasonal abundance of insects is a fact, and that rises in temperature and the first rains, both of which occur at the end of September and start of October and seem to be directly related to the increased abundance of these organisms.

\section{ACKNOWLEDGMENTS}

The authors thank scientific initiation program of the Centro Universitário de Brasília (UniCEUB) for the scholarship given to the first author; Antônio José de Cerqueira Antunes and Maria Luiza de Cerqueira Antunes for permitting us to conduct the study on their property; Inácio Siqueira for help with the fieldwork; and the National Institute of Meteorology of Goiás (Station $83376-10^{\circ}$ DISME/INMET Pirenópolis/GO), in the person of Zélia Macrina, for providing the climatic data for the municipality of Pirenópolis.

\section{REFERENCES}

Aiello, A. 1992. Dry season strategies of two Panamanian butterfly species, Anartia fatima (Nymphalinae) and Pierella luna luna (Satyrinae) (Lepidoptera: Nymphalidae), p. 573-575. In: D. Quintero Arias \& A. Aiello (eds.). Insects of Panama and Mesoamerica: Selected Studies. Oxford, Oxford University, $720 \mathrm{p}$.

Almeida, G. L. \& L. Marinoni. 2000. Abundância e sazonalidade das espécies de Leptoceridae (Insecta, Trichoptera) capturadas com armadilha luminosa no Estado do Paraná, Brasil. Revista Brasileira de Zoologia 17: 347-359.

Bispo, P. C. \& L. G. Oliveira. 2007. Diversity and structure of Ephemeroptera, Plecoptera and Trichoptera (Insecta) assemblages from riffles in mountain streams of Central Brazil. Revista Brasileira de Zoologia 24: 283-293.

Bispo, P.C.; L. G. Oliveira; L. M. Bini \& K. G. Sousa. 2006. Ephemeroptera, Plecoptera and Trichoptera form riffles in mountain streams of Central Brazil: environmental factors influencing the distribution and abundance of immatures. Brazilian Journal of Biology 66: 611-622.

Brakefield, P. M. 1987. Geographic variability in, and temperature effects on, the phenology of Maniola jurtina and Pyronius tithonus (Lepidoptera, Sattrinae) in England and Wales. Ecological Entomology 12: $139-148$.

Castro, L. H. R.; A. M. Moreira \& E. D. Assad. 1994. Definição e regionalização dos padrões pluviométricos dos Cerrados brasileiros. p.13-23. In: E. D. Assad (ed.) Chuvas nos Cerrados: análise e espacialização. Brasília, Embrapa CPAC, Embrapa SPI, 423 p.

Constantino, R. 1999. Chave ilustrada para identificação dos gêneros de cupins (Insecta: Isoptera) que ocorrem no Brasil. Papéis Avulsos de Zoologia 40: 387-448.

Constantino, R. 2002. The pest termites of South America: taxonomy, distribution and status. Journal of Applied Entomology 126: 355-365. 
Davis, D. E. 1945. The annual cycle of plants, mosquitos, birds, and mammals in two brazilian forest. Ecological Monographs 15: 243 295.

Della-Lucia, T. M. C. \& J. M. Bento. 1993. Vôo nupcial ou revoada, p. 5459. In: T.M.C. Della-Lucia (ed.). As formigas cortadeiras. Viçosa, Folha de Viçosa, 262 p.

DeVries, P. J. 1987. The butterflies of Costa Rica and their natural history: Papillionidae, Pieridae, Nymphalidae. New York, Princeton University, $327 \mathrm{p}$.

Dias, B. F. S. 1996. Cerrados: uma caracterização, p. 11-25. In: B. F. S. Dias (ed.). Alternativas de desenvolvimento dos Cerrados: manejo e conservação dos recursos naturais renováveis. Brasília, Funatura, $97 \mathrm{p}$.

Dias, M. M. 2006. Lepidoptera, p. 175-216. In: C. Costa; S. Ide \& C. E. Simonka (eds.). Insetos imaturos: metamorfose e identificação. Ribeirão Preto, Holos, 249 p.

Dobzhansky, T. \& C. Pavan. 1950. Local and seasonal variations in relative frequencies of species of Drosophila in Brazil. Journal Animal Ecology 19: 1-14.

Duarte Júnior, J. A. \& C. Schlindwein. 2005. Riqueza, abundância e sazonalidade de Sphingidae (Lepidoptera) num fragmento de Mata Atlântica de Pernambuco, Brasil. Revista Brasileira de Zoologia 22: 662-666.

Durbin, J. \& G. S. Watson. 1950. Testing for serial correlation in least squares regression. 1. Biometrika 37: 409-428.

Feeny, P. 1970. Seasonal changes in oak leaf tannins and nutrients as a cause of spring feeding by winter moth caterpillars. Ecology 51: 565-581.

Frizzas M.R.; C. Omoto; S. Silveira Neto \& R. C. B. Moraes. 2003. Avaliação da comunidade de insetos durante o ciclo da cultura do milho em diferentes agroecossistemas. Revista Brasileira de Milho e Sorgo 2: 9-24.

Gnaspini, P.; R. B. Francini-Filho \& M. R. Burgierman. 2000. Abundance and seasonal activity of beetles (Coleoptera) in an Atlantic Forest reservation in São Paulo (Brazil). Revista Brasileira de Entomologia 44: 115-127.

Guimarães, J. H. \& D. S. Amorin. 2006. Diptera, p. 147-160. In: C. Costa; S. Ide \& C. E. Simonka (eds.). Insetos imaturos: metamorfose e identificação. Ribeirão Preto, Holos, 249 p.

Goldsmith, S. 2007. Density of longhorned beetles (Coleoptera: Cerambycidae) differs at different elevations in hawaiian montane forest. The Southwestern Naturalist 52: 364-370.

Huston, M. A. 1996. Biological diversity. The coexistence of species on changing landscapes. Cambridge, Cambridge University Press, 681 p.

IBGE. 2004. Mapa de biomas e de Vegetação. Disponível em: http:// www.ibge.gov.br/home/presidencia/noticias/noticia_impressao. php?id_noticia $=169$ (accessed 30 April 2008).

Iannuzzi, L.; A. C. D. Maia \& S. D. Vasconcelos. 2006. Ocorrência e sazonalidade de coleópteros buprestídeos em uma região de Caatinga nordestina. Biociências 14: 174-179.

Janzen, D. H. 1987. How moths pass the dry season in a Costa Rican dry forest. Insect Science and Application 8: 489-500.

Kittelson, P. M. 2004. Sources of variation in insect density on Lupinus arboreus Sims: effects of environment, source population and plant genotype. The American Midland Naturalist 152: 323-335.

Kovach, W. 2004. Oriana v. 2.02. Anglesey, Wales, Kovach Computing Services.

Marinoni, L. \& G. L. Almeida. 2000. Abundância e sazonalidade das espécies de Hydropsychidae (Insecta, Trichoptera) capturadas em armadilha luminosa no Estado do Paraná. Revista Brasileira de Zoologia 17: 283-299.

Marinoni, R. C. \& N. G. Ganho. 2003. Sazonalidade de Nyssodrysina lignaria (Bates) (Coleoptera, Cerambycidae, Lamiinae) no Estado do Paraná, Brasil. Revista Brasileira de Zoologia 20: 141-152.

Medeiros, L. G. S.; A. G. Bandeira \& C. Martius. 1999. Termite swarming in the northeastern Atlantic rain Forest of Brazil. Studies on Neotropical Fauna and Environment 34: 76-87.
Mill, A. E. 1983. Observations on Brazilian termite alate swarms and some structures used in the dispersal of reproductives (Isoptera: Termitidae). Journal of Natural History 17: 309-320.

Mittermeier, R. A.; P. R. Gil; M. Hoffman; J. Pilgrim; T. Brooks; C. G. Mittermeier; J. Lamoreux \& G. A. B. Fonseca. 2005. Hotspots revisited: Earth's biologically richestand most threatened terrestrial ecoregions. Washington, Conservation International, $392 \mathrm{p}$.

Monteiro, R. F.; M. V. Macedo; M. S. Nascimento \& R. S. F. Cury. 2007. Composição, abundância e notas sobre a ecologia de espécies de larvas de lepidópteros associadas a cinco espécies de plantas hospedeiras no Parque Nacional da Restinga de Jurubatiba, RJ. Revista Brasileira de Entomologia 51: 476-483.

Morais, H. C. \& I. R. Diniz. 2004. Herbívoros e herbivoria no Cerrado: lagartas como exemplo. p. 159-176. In: L. M. S. Aguiar \& A. J. A. Camargo. Cerrado: ecologia e caracterização. Brasília, Embrapa Cerrados, Embrapa Informação Tecnológica, 249 p.

Morais, H. C; I. R. Diniz \& D. M. S. Silva. 1999. Caterpillar seasonality in a central Brazilian cerrado. Revista de Biologia Tropical 47: 1025-1033.

Noriega, J. A.; J. P. Botero; M. Viola \& G. Fagua. 2007. Dinamica estacional de la estructura trofica de un ensamblaje de Coleoptera en la Amazonia Colombiana. Revista Colombiana de Entomologia 33: 157-164.

Oliveira, A. F.; R. L. M. Ferreira \& J. A. Rafael. 2007a. Sazonalidade e atividade diurna de Tabanidae (Diptera: Insecta) de dossel na Reserva Florestal Adolpho Ducke, Manaus, AM. Neotropical Entomology 36: 790-797.

Oliveira, C. M.; D. V. S. Resck \& M. R. Frizzas. 2006. Artrópodes edáficos: influência do sistema de preparo do solo e rotação de culturas. Planaltina, Embrapa Cerrados, 26 p. (Embrapa Cerrados. Boletim de Pesquisa e Desenvolvimento, 160).

Oliveira, C. M.; M. A. Morón \& M. R. Frizzas. 2007b. First record of Phyllophaga sp. aff. capillata (Coleoptera: Melolonthidae) as a soybean pest in the brazilian "Cerrado". Florida Entomologist 90: 772-775.

Oliveira, C. M.; M. A. Morón \& M. R. Frizzas. 2008. Aegopsis bolboceridus (Coleoptera: Melolonthidae): an important pest on vegetables and corn in Central Brazil. Florida Entomologist 91: 324-327.

Oliveira, P. E. A. M. 2008. Fenologia e biologia reprodutiva das espécies de Cerrado, p. 273-290. In: S. M. Sano; S. P. Almeida \& J. F. Ribeiro (eds.). Cerrado: ecologia e flora. Vol. Brasília, Embrapa Informação Tecnológica, $406 \mathrm{p}$.

Ott, A. P.; W. S. Azevedo-Filho; A. Ferrari \& G. S. Carvalho. 2006. Abundância e sazonalidade de cigarrinhas (Hemiptera, Cicadellidae, Cicadellinae) em vegetação herbácea de pomar de laranja doce, no município de Montenegro, Estado do Rio Grande do Sul, Brasil. Iheringia, Série Zoologia 96: 425-429.

Pinheiro, F.; I. R. Diniz; D. Coelho \& M. P. S. Bandeira. 2002. Seasonal pattern of insect abundance in the Brazilian cerrado. Austral Ecology 27: $132-136$.

Pinto, R.; J. S. Zanuncio-Junior; J. A. M. Ferreira \& J. C. Zanuncio. 2000. Flutuação populacional de Coleoptera em plantio de Eucalyptus urophylla no município de Três Marias, Minas Gerais. Floresta e Ambiente 7: 143-151.

Ribeiro, J. F. \& B. M. T. Walter. 2008. As principais fitofisionomias do bioma Cerrado, p. 151-212. In: S. M. Sano; S. P. Almeida; J. F. Ribeiro (eds.). Cerrado: ecologia e flora. Vol. 2, Brasília, Embrapa Informação Tecnológica, 406 p.

Sano, E. E.; R. Rosa; J. L. S. Brito \& L. G. Ferreira. 2008. Mapeamento semidetalhado do uso da terra do Bioma Cerrado. Pesquisa Agropecuária Brasileira 43: 153-156.

SAS Institute. 2001. SAS/STAT user's guide: statistics. V. 2, 5. ed. Version 8.02, Cary, NC, 943 p.

Shuvartz, M.; L. G. Oliveira; J. A. F. Diniz-Filho \& L. M. Bini. 2005. Relações entre distribuição e abundância de larvas de Trichoptera. Acta Scientiarum. Biological Sciences 27: 51-55.

Silva, F. A. M.; E. A. Assad \& B. A. Evangelista. 2008. Caracterização climática do bioma Cerrado. p. 69-88. In: S. M. Sano; S. P. Almeida; J. F. Ribeiro (eds.). Cerrado: ecologia e flora. Vol. 2, Brasília, Embrapa Informação Tecnológica, 406 p.

Silveira-Neto, S.; R. C. Monteiro; R. A. Zucchi \& R. C. B. Moraes. 1995. 
Uso da análise faunística de insetos na avaliação do impacto ambiental. Scientia Agricola 52: 9-15.

Teskey, H. J. 1991. Introduction, p. 690-706. In: B. A. Foote (coord.). Order Diptera, cap. 37, p. 609-915. In: F. W. Stehr (ed.). Immature insects. Dubunque, Kendall/Hunt Publishing Company, vol. 2, 975 p.

Torres, F. R. \& L. Madi-Ravazzi. 2006. Seasonal variation in natural populations of Drosophila spp. (Diptera) in two woodlands in the State of São Paulo, Brazil. Iheringia, Série Zoologia, 96: 437-444.

Wolda, H. 1978. Seasonal fluctuations in rainfall, food and abundance of tropical insects. Journal of Animal Ecology 47: 369-381.
Wolda, H. 1980. Seasonality of tropical insects. I. Leafhoppers (Homoptera) in Las Cumbres, Panama. Journal of Animal Ecology 49: 277-290.

Wolda, H. 1988. Insect seasonality: why? Annual Review of Ecology and Systematics 19: 1-18.

Wolda, H. 1992. Trends in abundance of tropical forest insects. Oecologia 89: $47-52$.

Wolda, H. \& F. W. Fisk. 1981. Seasonality of tropical insects. II. Blattaria in Panama. Journal of Animal Ecology 50: 827-838.

Zar, J. H. 1999. Biostatistical Analysis, 4th ed., New Jersey, Prentice Hall, $663 \mathrm{p}$. 